\title{
Comportamento ingestivo de éguas da raça Crioula prenhes e em lactação
}

João Danilo Biffi Pereira", Marcele Sousa Vilanova, Catia Dal Bello Giacomet, Caroline Braga Andelieri, Willian Perin

Universidade de Caxias do Sul(UCS), Caxias do Sul, RS, Brasil

*Autor correspondente

e-mail: joao.danilo@hotmail.com

\section{Resumo}

O bem-estar animal é uma ciência em desenvolvimento, que busca as relações mais respeitosas entre os humanos e os animais. Uma das bases fundamentais para a manutenção desse equilíbrio é o entendimento das variáveis comportamentais que influenciam os animais em pastejo, pois desde a domesticação dos equinos, diversas são as situações de manejo alimentar inadequadas resultantes do restrito conhecimento desses animais a campo. 0 objetivo do trabalho foi avaliar o comportamento ingestivo de éguas de raça Crioula, prenhes e com potro ao pé, em pastagem de campo nativo melhorado, durante os turnos da manhã, meio-dia e tarde. 0 experimento foi realizado na Cabanha Tamboré, localizada no município de São Francisco de Paula/RS. Foram selecionadas oito éguas com idade média de 9 anos, prenhes (entre 120 a 180 dias gestação) com potros ao pé. Os animais foram alocados em um potreiro de 8 ha, composto por pastagem nativa, melhorada com trevo branco, trevo vermelho e cornichão. A coleta dos dados foi realizada nos dias 24, 25 e 26 de março de 2017, durante o período das 8h às 18h. Foram anotadas as frequências de realização dos comportamentos de pastejo, deslocamento, ingestão de água e de sal mineral, descansando, mastigando, defecando/urinando, se coçando, potro mamando, interação égua com égua e interação égua com potro. 0 método de avaliação utilizado foi do etograma, técnica de amostragem do animal focal, com intervalos de 10/10 minutos entre as observações (Del-Claro, 2004). 0 tempo despendido com os comportamentos foi transformado em percentual (tendo como base 600 minutos totais de avaliação), os dados foram submetidos à análise da variância e as médias comparadas pelo teste de Tukey (5\%). A frequência percentual total despendida com os comportamentos foi de 77,0 em pastejo; 11,7 descansando; 4,03 em deslocamento; 2,12 com potro mamando; 1,32 mastigando; 0,84 ingerindo sal; 0,77 defecando/urinando; 0,64 de interação égua/potro; 0,6 bebendo água; 0,44 de interação égua/égua; 0,41 coçando. Os comportamentos que foram influenciados pelo turno de avaliação foram: Deslocamento (Manhã: 2,09a; Meio-dia: 0,83b; Tarde: 1,11b), 
ingerindo sal (Manhã: 0,14b; Meio-dia: 0,63a; Tarde: 0,07b) e interação égua/potro (Manhã: 0,00b; Meiodia: 0,14ab; Tarde: 0,5a). Como esperado, os equinos utilizam a maior parte do tempo com a atividade de colheita de alimento. Segundo Zanine et al. (2006), das $24 \mathrm{~h}$ avaliadas, as éguas gastaram em média 16,7h $(69,5 \%)$, das quais o maior tempo se concentra das $16 \mathrm{~h}$ às $19 \mathrm{~h}$. De acordo com Rifá (1990), as éguas em lactação utilizam em média 59\% do dia para o pastejo e $40 \%$ para descanso e outras atividades. Resultado este, um pouco inferior ao encontrado neste trabalho (77\%), possivelmente em função de as avaliações terem sido realizadas até as $18 \mathrm{~h}$. Diferença que pode ser justificada em função dos equinos continuarem patejando até $1 \mathrm{~h}$ (Zanine et. al., 2006). 0 conhecimento das atividades realizadas pelas éguas gestantes e em lactação pode auxiliar os manejadores na escolha dos melhores períodos de manuseio desses animais e confinamento, quando necessário, visando a busca incessante pelo bem-estar animal nas criações de equinos.

Palavras-chave: Bem-estar animal. Pastejo. Campo nativo. 